\title{
Anthropogenic sediments from facultative lagoons of the Konstancin-Jeziorna sewage treatment facility and their usability for soil recultivation
}

\author{
Paulina Kostrz-Sikora, Izabela Bojakowska, Stanisław Wołkowicz, \\ Przemysław Dobek, Dariusz Lech, Wanda Narkiewicz
}

The Polish Geological Institute - National Research Institute; ul. Rakowiecka 4, 00-975 Warsaw, Poland; e-mail: paulina.kostrz-sikora@pgi.gov.pl

\begin{abstract}
(C) 2015 Authors. This is an open access publication, which can be used, distributed and reproduced in any medium according
\end{abstract} to the Creative Commons CC-BY 4.0 License requiring that the original work has been properly cited.

Received: January 2015; accepted: May 2015

\begin{abstract}
The sewage treatment facility of a paper mill at Konstancin-Jeziorna was opened to process industrial and domestic wastewater. After closure of that mill, the sewage treatment facility had to be rebuilt and modernized. Therefore, it was necessary to analyse the chemical and phase composition of the sediments from facultative lagoons used for biological treatment of wastewater. Eight samples of sediments were taken to identify a general phase composition by X-ray diffraction and ten to determine concentrations of selected main and trace elements with the use of ICP-AES and AMA methods.

The analyses showed that the sediments consisted of over $90 \%$ of mineral fraction, mainly kaolinite, calcite, and quartz and also neomorphic smithsonite. They contained low quantities of $\mathrm{Hg}$, Cd, Co and Mo, and elevated concentrations of $\mathrm{Zn}, \mathrm{Ba}, \mathrm{Mn}$ and $\mathrm{Sr}$. Comparisons of the obtained mean values with admissible concentrations of metals, as defined by Regulation of the Minister of Environment of 9 September 2002, showed that the mean concentrations of As, Sn, Co, Mo and $\mathrm{Ni}$ (and also of $\mathrm{Hg}$ and $\mathrm{Cr}$ in the southern lagoon) met quality standards for soils in areas under protection (group A). Mean concentrations of $\mathrm{Pb}$ (both lagoons), $\mathrm{Ba}, \mathrm{Cu}, \mathrm{Cd}$ (northern lagoon) as well as $\mathrm{Cr}$ and $\mathrm{Hg}$ (southern lagoon) in sediments are higher. However, they still meet standards for areas usable for agricultural and other purposes (group B). The highest concentrations were recorded for $\mathrm{Zn}, \mathrm{Cd}$, $\mathrm{Cu}$ and $\mathrm{Ba}$ in samples from the southern lagoon. These continued to be lower than all the limits acceptable for industrial areas.
\end{abstract}

Keywords: anthropogenic soils, heavy metals, revitalization

\section{INTRODUCTION}

The history of the Konstancin-Jeziorna paper mill can be traced back to the 1780's and Johann Joseph Felix von Kurz known as Bernardon, a Viennese actor with outstanding managerial and supervisory skills. His vast business experience helped him to recognize and make use of business opportunities in the Warsaw region resulting from steady growth in demand for paper in offices, schools and print shops, accompanied by a lack of any large local producers to compete with. The key to success was his ability to make King Stanisław August Poniatowski interested in the project of establishing a paper mill at Jeziorna. The project proved to be very attractive, as it took on the production of good quality laid paper from rags collected by the poor, which provided them work from which they could earn money (Dąbrowski 2011). In result, King Poniatowski became a co-founder of 
this project and, this way, the dream of Johann J.F. Kurz became a reality. His paper mill got the status of a royal manufacturer and could place the King's coat of arms in the watermark of the produced laid paper.

The paper supplied by the Jeziorna paper mill played a significant role in the most important events in the history of Poland, in the last decades of the $18^{\text {th }}$ century, being widely used in works of the Great Sejm, printing the text of The Constitution of $3^{\text {rd }}$ May, 1791 as well as in the production of the first Polish paper currency. After further expansion and installation of modern Hollander beaters for production of cellulose containing plant fibers, the Jeziorna paper mill became one of the largest in Poland and the largest in the Warsaw region.

In the $19^{\text {th }}$ century, whirlwinds of history and related changes in the market repeatedly put the future of the Jeziorna paper mill at risk. Nevertheless, the mill appeared capable to maintain its importance. The significant milestones being 1812, when the mill got the title of the Royal Paper Manufacturing Factory, as well as 1830, when it was taken over by the Polish Bank (Bank Polski). Finally in 1838, paper production became mechanized. The next important event in history of the paper mill took place at the start of the $20^{\text {th }}$ century, when the Mirków Paper Manufacturing Joint-Stock Company became interested in the Jeziorna paper mill. This resulted in a merger of the enterprises and establishment of the Mirków Paper Manufacturing Company based at Jeziorna. The First World War significantly impeded successful operations of this new entity, leading to its temporary closure. The production was successfully recommenced in 1917, with reconstruction and modernization of the mill continuing for about 10 years.

At the outbreak of the Second World War, the Jeziorna paper mill had full production capability. After it was closed during the military operations of September 1939, production recommenced under control of the occupation authorities to continue until the autumn of 1944, when the Nazi Germans sent workers to concentration camps and began to loot the machinery of the mill leading to its systematic demolition. After the end of the war, the mill was rebuilt to be nationalized in 1947. Soon thereafter it was merged with 6 other enterprises to form the Warsaw Paper Manufacturing Factory. Following restructurisation and modernization, the Jeziorna paper mill reached its pre-war production levels in 1951. Subsequent investments led to dynamic growth of both the enterprise and the adjacent area.

When the Polish government began to implement the mass privatization programs of stateowned businesses in the mid-1990s, ownership shares of the Warsaw Paper Manufacturing Factory were passed to the Polish National Investment Funds, and, subsequently, the majority of shareholding went to a Finnish company, Metsä Tissue. This company was mainly interested in the hygienic and sanitary paper products market and, therefore, the parts of the paper mill with production lines of cardboard, writing paper and parchment were bought by Konstans Co. Ltd. The parts producing felt paper and paperboard were leased by Ecotex Polska Co. Ltd.

In 2010, the history of the Jeziorna paper mill came to an end after almost 250 years, when the Konstans Company decided to phase out production and closed its part of the mill, techinically considered obsolete. This decision was soon also taken by the Ecotex company as well as Metsä Tissue, which transferred its whole production from Jeziorna to its factory at Krapkowice by the end of 2012 (Gadomska, website).

The shutdown of the Jeziorna paper mill meant the simultaneous closure of its mechanical-biological wastewater treatment facility. Since its opening in 1961, the facility operated as an element of the technological line of the mill, designed to treat both process wastewater and domestic wastewater from neighboring areas. The biological section of this facility included a facultative lagoon, partly separated into two sections by an intermediate dyke. This was a type of stabilization pond used for biological treatment, in which biological sediment could accumulate. After the shutdown of the mill, and, before the start of revitalization, the dyke was extended to achieve full separation of the lagoon into two parts, the northern lagoon and the southern.

One of the main stages of revitalization was connected with the removal of sediments, accumulated on the floor of the lagoons. The sediments have to be treated as anthropogenic soils; 
i.e. soils originating as a result of economic activity of people, created by people, or caused by human activity. They include solid waste and relocated and re-deposited natural soils" (Drągowski 2010). This approach was in accordance with the water-law permit obtained by the operator, who was obliged to periodically remove sediments accumulating on the facultative lagoon floor. Suspended matter originating as a result of the continuous work of aerators was pumped and removed for a few months every year, making it possible to stop classifying sediments accumulating on the lagoon floor as waste, under the code 190812 (sludge from biological treatment of industrial wastewater other than those classified under the code 1908 11). This interpretation was supported by the results of assessments of the total amount of carbon occurring in organic compounds (TOC), conducted in 2012. The data obtained showed that the content of organic matter in the sediments from the lagoon floor equals $7.32 \%$ on average (Bojakowska et al. 2012) and in wet sludge sediments - about $60 \%$ on average, ranging from $36 \%$ to $80 \%$ (Bień \& Wystalska 2011). Therefore, the terms "sediments" and "anthropogenic soils" are used interchangeably later in the present paper.

\section{FIELD WORKS}

The field works on the northern and southern lagoons were carried out separately. They were conducted in stages comprising successive rounds of sampling of the lagoon floor sediments. In total, 8 samples were taken in 2012 and the next 10 samples in 2013 (7 samples from the southern lagoon and 3 from the northern). Figure 1 shows the location of sites sampled in the year 2013.

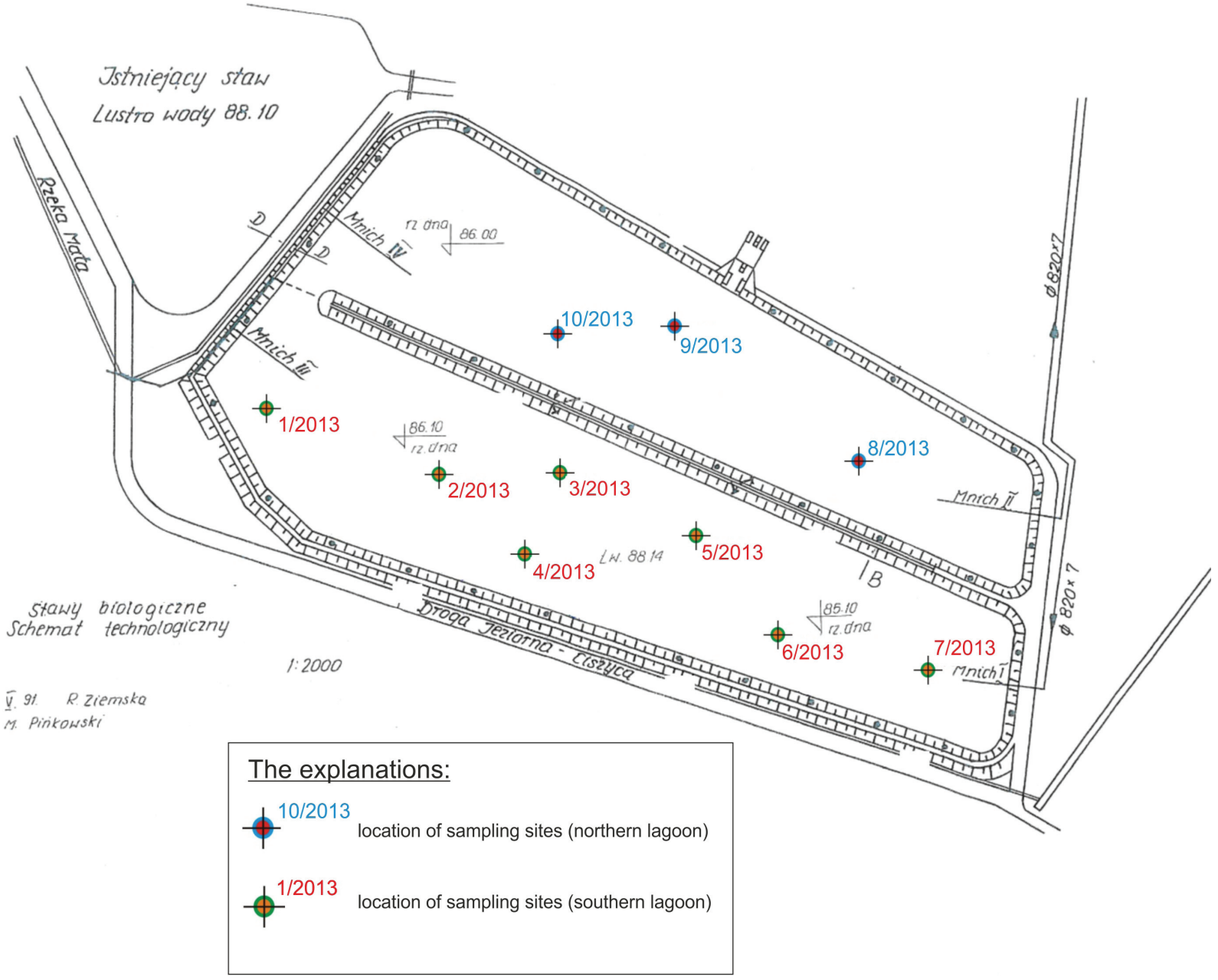

Fig. 1. Location of sampling sites 


\section{THE RANGE AND METHODS OF ANALYSES}

Samples taken in 2012 were subjected to X-ray diffraction (XRD) analysis to identify their general phase composition. In turn, the material collected in 2013 was dissolved in aqua regia to determine contents of $\mathrm{As}, \mathrm{Ba}, \mathrm{Cd}, \mathrm{Cr}, \mathrm{Co}, \mathrm{Cu}, \mathrm{Mo}, \mathrm{Ni}, \mathrm{Pb}, \mathrm{Sn}$, $\mathrm{Sr}, \mathrm{V}, \mathrm{Zn}, \mathrm{Al}, \mathrm{Ca}, \mathrm{Fe}, \mathrm{K}, \mathrm{Mg}, \mathrm{Mn}, \mathrm{Na}, \mathrm{P}$ and $\mathrm{S}$, with the use of atomic emission spectrometry, with an excitation in the inductively coupled plasma (ICP-AES). Moreover, contents of $\mathrm{Hg}$ were determined by absorption spectrometry, with the use of an amalgamator (AMA).

\section{DISCUSSION OF RESULTS}

X-ray diffraction (XRD) analyses showed that the lagoon bottom sediments consist of over $90 \%$ of mineral fraction. The X-ray diffractograms showed that the sediments mainly consist of kaolinite (with a share of $30 \%$ ), calcite (about $25 \%$ ) and quartz (about 15\%). Moreover, neomorphic smithsonite was found to be present in trace amounts of two samples. Some admixtures of feldspars, dolomite, hematite and pyrite were also recorded.

Table 1 shows the results of the analysis of the general phase composition as established for individual samples. One should note that, the arrangement of minerals identified and listed in each sample in Table 1 is according to their decreasing percentage.
Table 2 shows concentrations of elements in the soil samples, Table 3 - statistical parameters (arithmetic mean, geometric mean and median, minimum and maximum values).

Analysis of data from Table 2 shows that all concentrations of $\mathrm{Hg}, \mathrm{Cd}, \mathrm{Co}, \mathrm{Mo}$ and $\mathrm{As}$ in the studied sediments were lower than $10 \mathrm{mg} / \mathrm{kg}$. Concentrations of $\mathrm{Hg}$ in sediments from both lagoons appeared to be lower than $1 \mathrm{mg} / \mathrm{kg}$. In sediments from the southern lagoon they ranged from 0.405 to $0.902 \mathrm{mg} / \mathrm{kg}$ (being equal $0.716 \mathrm{mg} / \mathrm{kg}$ on average) and in those from the northern lagoon - from 0.382 to $0.582 \mathrm{mg} / \mathrm{kg}$ ( $0.486 \mathrm{mg} / \mathrm{kg}$ on average). Concentrations of Cd ranged from 2.1 to $8.2 \mathrm{mg} / \mathrm{kg}$ in all the studied sediments, but in a narrower range in the case of those from the northern lagoon - merely from 2.1 to $2.7 \mathrm{mg} / \mathrm{kg}$. Mean concentrations of $\mathrm{Cd}$ in sediments from the southern lagoon were equal $4.2 \mathrm{mg} / \mathrm{kg}$ and, in those from the northern lagoon, $2.4 \mathrm{mg} / \mathrm{kg}$. Concentrations of Co in the studied sediments ranged from 2.0 to $8.0 \mathrm{mg} / \mathrm{kg}$ and from 3.0 to $7.0 \mathrm{mg} / \mathrm{kg}$ in sediments from the northern lagoon. Mean concentrations of Co in sediments from the southern lagoon were $4.0 \mathrm{mg} / \mathrm{kg}$ and in those from the northern lagoon $-5.0 \mathrm{mg} / \mathrm{kg}$. Concentrations of the last of these elements, Mo, ranged from 3.3 to $6.7 \mathrm{mg} / \mathrm{kg}$ in sediments from the southern lagoon and from 2.9 to $4.5 \mathrm{mg} / \mathrm{kg}$ in those from the northern one, being 4.4 and $4.0 \mathrm{mg} / \mathrm{kg}$ on average, respectively. Concentrations of As were found to range from 4.0 to $8.0 \mathrm{mg} / \mathrm{kg}$ equal to $6.0 \mathrm{mg} / \mathrm{kg}$ on average in sediments from both lagoons.

Table 1

Crystalline phases identified in the soil samples

\begin{tabular}{|c|l|}
\hline Sample number & \multicolumn{1}{|c|}{ The results of X-ray diffraction (XRD analysis) } \\
\hline $1 / 2012$ & $\begin{array}{l}\text { calcite, quartz, clay minerals (kaolinite, traces of illite and talc), admixture of feldspars, dolomite and } \\
\text { trace of smithsonite }\end{array}$ \\
\hline $2 / 2012$ & $\begin{array}{l}\text { calcite, quartz, clay minerals (kaolinite, traces of illite), admixture of feldspars, dolomite and traces } \\
\text { of smithsonite and pyrite }\end{array}$ \\
\hline $3 / 2012$ & calcite, quartz, clay minerals (kaolinite) \\
\hline $4 / 2012$ & calcite, quartz, clay minerals (kaolinite), admixture of feldspars, dolomite \\
\hline $5 / 2012$ & calcite, quartz, clay minerals (kaolinite, illite/ muscovite), feldspars, trace of hematite \\
\hline $6 / 2012$ & quartz, calcite, clay minerals (kaolinite, illite/ muskovite), feldspars, traces of hematite \\
\hline $7 / 2012$ & calcite, quartz, clay minerals (kaolinite, traces of illite), trace of dolomite and pyrite \\
\hline $8 / 2012$ & quartz, calcite, clay minerals (kaolinite, traces of illite), admixture of feldspars, pyrite and dolomite \\
\hline
\end{tabular}


Table 2

Contents of the elements in anthropogenic soils collected from southern lagoon and northern lagoon in 2013

\begin{tabular}{|c|c|c|c|c|c|c|c|c|c|c|c|}
\hline \multirow{3}{*}{ Element } & \multirow{3}{*}{ Unit } & \multicolumn{7}{|c|}{ Southern lagoon } & \multicolumn{3}{|c|}{ Northern lagoon } \\
\hline & & \multicolumn{10}{|c|}{ Sample number } \\
\hline & & $1 / 2013$ & $2 / 2013$ & $3 / 2013$ & $4 / 2013$ & $5 / 2013$ & $6 / 2013$ & $7 / 2013$ & $8 / 2013$ & $9 / 2013$ & $10 / 2013$ \\
\hline Arsenic & $\mathrm{mg} / \mathrm{kg}$ & 5 & 6 & 7 & 4 & 6 & 7 & 8 & 4 & 6 & 8 \\
\hline Barium & $\mathrm{mg} / \mathrm{kg}$ & 516 & 464 & 444 & 356 & 278 & 607 & 150 & 145 & 609 & 122 \\
\hline Chromium & $\mathrm{mg} / \mathrm{kg}$ & 43 & 47 & 67 & 37 & 43 & 57 & 65 & 25 & 43 & 45 \\
\hline Tin & $\mathrm{mg} / \mathrm{kg}$ & 9 & 10 & 13 & 6 & 16 & 12 & 14 & 7 & 9 & 7 \\
\hline Zinc & $\mathrm{mg} / \mathrm{kg}$ & 868 & 869 & 1390 & 671 & 1321 & 1084 & 1303 & 550 & 653 & 738 \\
\hline Cadmium & $\mathrm{mg} / \mathrm{kg}$ & 3.1 & 2.9 & 4.2 & 2.7 & 8.2 & 3.1 & 4.9 & 2.5 & 2.1 & 2.7 \\
\hline Cobalt & $\mathrm{mg} / \mathrm{kg}$ & 3 & 3 & 3 & 7 & 8 & 2 & 4 & 5 & 3 & 7 \\
\hline Manganese & $\mathrm{mg} / \mathrm{kg}$ & 313 & 292 & 254 & 357 & 568 & 198 & 195 & 319 & 342 & 286 \\
\hline Copper & $\mathrm{mg} / \mathrm{kg}$ & 177 & 178 & 185 & 126 & 378 & 169 & 250 & 169 & 141 & 133 \\
\hline Molybdenium & $\mathrm{mg} / \mathrm{kg}$ & 3.9 & 3.5 & 4.7 & 3.4 & 6.7 & 3.3 & 5.0 & 2.9 & 4.5 & 4.5 \\
\hline Nickel & $\mathrm{mg} / \mathrm{kg}$ & 16 & 15 & 15 & 26 & 29 & 14 & 18 & 17 & 15 & 27 \\
\hline Lead & $\mathrm{mg} / \mathrm{kg}$ & 76 & 80 & 122 & 49 & 62 & 105 & 111 & 39 & 78 & 79 \\
\hline Mercury & $\mathrm{mg} / \mathrm{kg}$ & 0.662 & 0.672 & 0.902 & 0.405 & 0.802 & 0.707 & 0.861 & 0.382 & 0.582 & 0.495 \\
\hline Strontium & $\mathrm{mg} / \mathrm{kg}$ & 245 & 193 & 125 & 199 & 301 & 106 & 119 & 130 & 220 & 111 \\
\hline Vanadium & $\mathrm{mg} / \mathrm{kg}$ & 9 & 10 & 10 & 21 & 12 & 8 & 10 & 9 & 10 & 25 \\
\hline Phosphorus & $\%$ & 0.551 & 0.541 & 0.499 & 0.554 & 1.009 & 0.471 & 0.516 & 0.492 & 0.599 & 0.419 \\
\hline Aluminum & $\%$ & 1.66 & 1.84 & 2.21 & 1.28 & 1.08 & 1.93 & 1.87 & 0.88 & 1.47 & 1.96 \\
\hline Magnesium & $\%$ & 0.26 & 0.27 & 0.18 & 0.30 & 0.32 & 0.16 & 0.19 & 0.18 & 0.27 & 0.30 \\
\hline Potassium & $\%$ & 0.069 & 0.075 & 0.071 & 0.090 & 0.057 & 0.064 & 0.067 & 0.053 & 0.062 & 0.110 \\
\hline Sulfur & $\%$ & 0.971 & 0.748 & 0.750 & 1.226 & 2.793 & 0.597 & 1.003 & 0.996 & 0.727 & 0.940 \\
\hline Sodium & $\%$ & 0.040 & 0.036 & 0.034 & 0.029 & 0.057 & 0.030 & 0.043 & 0.043 & 0.045 & 0.038 \\
\hline Calcium & $\%$ & 14.3 & 12.9 & 8.0 & 9.9 & 13.5 & 6.2 & 6.7 & 6.15 & 13.77 & 5.67 \\
\hline Iron & $\%$ & 1.08 & 0.97 & 0.76 & 2.48 & 3.07 & 0.65 & 1.13 & 1.22 & 0.78 & 1.71 \\
\hline
\end{tabular}

Table 3

Statistical parameters of elements in sewage sludge collected from a southern lagoon and northern lagoon in 2013

\begin{tabular}{|l|c|c|c|c|c|c|c|c|c|c|c|}
\hline \multirow{2}{*}{ Element } & \multirow{2}{*}{ Unit } & \multicolumn{4}{|c|}{ Southern lagoon } & \multicolumn{5}{c|}{ Northern lagoon } \\
\cline { 3 - 16 } & & $\begin{array}{c}\text { arith- } \\
\text { metic } \\
\text { mean }\end{array}$ & $\begin{array}{c}\text { geo- } \\
\text { metric } \\
\text { mean }\end{array}$ & median & min. & max. & $\begin{array}{c}\text { arith- } \\
\text { metic } \\
\text { mean }\end{array}$ & $\begin{array}{c}\text { geo- } \\
\text { metric } \\
\text { mean }\end{array}$ & median & min. & max. \\
\hline Arsenic & $\mathrm{mg} / \mathrm{kg}$ & 6 & 6 & 6 & 4 & 8 & 6 & 6 & 6 & 4 & 8 \\
\hline Barium & $\mathrm{mg} / \mathrm{kg}$ & 402 & 370 & 444 & 150 & 607 & 292 & 221 & 145 & 122 & 609 \\
\hline Chromium & $\mathrm{mg} / \mathrm{kg}$ & 51 & 50 & 47 & 37 & 67 & 38 & 36 & 43 & 25 & 45 \\
\hline Tin & $\mathrm{mg} / \mathrm{kg}$ & 11 & 11 & 12 & 6 & 16 & 8 & 8 & 7 & 7 & 9 \\
\hline Zinc & $\mathrm{mg} / \mathrm{kg}$ & 1072 & 1040 & 1084 & 671 & 1390 & 647 & 643 & 653 & 550 & 738 \\
\hline Cadmium & $\mathrm{mg} / \mathrm{kg}$ & 4.2 & 3.9 & 3.1 & 2.7 & 8.2 & 2.4 & 2.4 & 2.5 & 2.1 & 2.7 \\
\hline
\end{tabular}


Table 3 cont.

\begin{tabular}{|c|c|c|c|c|c|c|c|c|c|c|c|}
\hline \multirow[b]{2}{*}{ Element } & \multirow[b]{2}{*}{ Unit } & \multicolumn{5}{|c|}{ Southern lagoon } & \multicolumn{5}{|c|}{ Northern lagoon } \\
\hline & & $\begin{array}{l}\text { arith- } \\
\text { metic } \\
\text { mean }\end{array}$ & $\begin{array}{c}\text { geo- } \\
\text { metric } \\
\text { mean }\end{array}$ & median & $\min$. & $\max$ & $\begin{array}{l}\text { arith- } \\
\text { metic } \\
\text { mean }\end{array}$ & $\begin{array}{l}\text { geo- } \\
\text { metric } \\
\text { mean }\end{array}$ & median & $\min$. & $\max$. \\
\hline Cobalt & $\mathrm{mg} / \mathrm{kg}$ & 4 & 4 & 3 & 2 & 8 & 5 & 5 & 5 & 3 & 7 \\
\hline Manganese & $\mathrm{mg} / \mathrm{kg}$ & 311 & 292 & 292 & 195 & 568 & 316 & 315 & 319 & 286 & 342 \\
\hline Copper & $\mathrm{mg} / \mathrm{kg}$ & 209 & 197 & 178 & 126 & 378 & 147 & 147 & 141 & 133 & 169 \\
\hline Molybdenium & $\mathrm{mg} / \mathrm{kg}$ & 4.4 & 4.2 & 3.9 & 3.3 & 6.7 & 4.0 & 3,9 & 4,5 & 2,9 & 4,5 \\
\hline Nickel & $\mathrm{mg} / \mathrm{kg}$ & 19 & 18 & 16 & 14 & 29 & 20 & 19 & 17 & 15 & 27 \\
\hline Lead & $\mathrm{mg} / \mathrm{kg}$ & 86 & 83 & 80 & 49 & 122 & 66 & 62 & 78 & 39 & 79 \\
\hline Mercury & $\mathrm{mg} / \mathrm{kg}$ & 0.716 & 0.696 & 0.707 & 0.405 & 0.902 & 0.486 & 0.479 & 0.495 & 0.382 & 0.582 \\
\hline Strontium & $\mathrm{mg} / \mathrm{kg}$ & 184 & 172 & 193 & 106 & 301 & 154 & 147 & 130 & 111 & 220 \\
\hline Vanadium & $\mathrm{mg} / \mathrm{kg}$ & 11 & 11 & 10 & 8 & 21 & 15 & 13 & 10 & 9 & 25 \\
\hline Phosphorus & $\%$ & 0.592 & 0.573 & 0.541 & 0.471 & 1.009 & 0.503 & 0.498 & 0.492 & 0.419 & 0.599 \\
\hline Aluminum & $\%$ & 1.70 & 1.65 & 1.84 & 1.08 & 2.21 & 1.43 & 1.36 & 1.47 & 0.88 & 1.96 \\
\hline Magnesium & $\%$ & 0.24 & 0,23 & 0.26 & 0.16 & 0.32 & 0.25 & 0.24 & 0.27 & 0.18 & 0.30 \\
\hline Potassium & $\%$ & 0.070 & 0.070 & 0.069 & 0.057 & 0.090 & 0.075 & 0.071 & 0.062 & 0.053 & 0.110 \\
\hline Sulfur & $\%$ & 1.155 & 1.016 & 0.971 & 0.597 & 2.793 & 0.888 & 0.880 & 0.940 & 0.727 & 0.996 \\
\hline Sodium & $\%$ & 0.038 & 0.037 & 0.036 & 0.029 & 0.057 & 0.042 & 0.042 & 0.043 & 0.038 & 0.045 \\
\hline Calcium & $\%$ & 10.19 & 9.69 & 9.88 & 6.20 & 14.25 & 8.53 & 7.83 & 6.15 & 5.67 & 13.77 \\
\hline Iron & $\%$ & 1.45 & 1.24 & 1.08 & 0.65 & 3.07 & 1.24 & 1.18 & 1.22 & 0.78 & 1.71 \\
\hline
\end{tabular}

The elements occurring at the higher than $100 \mathrm{mg} / \mathrm{kg}$ concentrations in all the studied sediments included $\mathrm{Zn}, \mathrm{Ba}, \mathrm{Mn}, \mathrm{Sr}$ and $\mathrm{Cu}$. Concentrations of $\mathrm{Zn}$ were found to range from 671 to $1,390 \mathrm{mg} / \mathrm{kg}$ in sediments from the southern lagoon and from 550 to $738 \mathrm{mg} / \mathrm{kg}$ in those from the northern one, equal to $1,072 \mathrm{mg} / \mathrm{kg}$ and $647 \mathrm{mg} / \mathrm{kg}$ on average, respectively. Similarly high variability in concentrations was recorded in the case of $\mathrm{Ba}$. Concentrations of that element ranged from 150 to $607 \mathrm{mg} / \mathrm{kg}$ in sediments from the southern lagoon and from 122 to $609 \mathrm{mg} / \mathrm{kg}$ in those from the northern one, equal to $402 \mathrm{mg} / \mathrm{kg}$ and $292 \mathrm{mg} / \mathrm{kg}$ on average, respectively. In turn, concentrations of $\mathrm{Mn}$ were found to range from 195 to $568 \mathrm{mg} / \mathrm{kg}$. These concentrations appeared similar in sediments from both lagoons, amounting to to $311 \mathrm{mg} / \mathrm{kg}$ and $316 \mathrm{mg} / \mathrm{kg}$ in those from the southern and northern lagoon. Concentrations of Sr were found to be lower, equal to $184 \mathrm{mg} / \mathrm{kg}$ and $154 \mathrm{mg} / \mathrm{kg}$ on average in sediments from the southern and northern lagoon, respectively. Concentrations of $\mathrm{Cu}$ were found to have a wide range in sediments from the southern lagoon, from 126 to $378 \mathrm{mg} / \mathrm{kg}$ (209 mg/kg average), and in somewhat narrower range in those from the northern lagoon, from 133 to $169 \mathrm{mg} / \mathrm{kg}$ ( $147 \mathrm{mg} / \mathrm{kg}$ average).

Of the remaining parameters used in this study, concentrations of Cr ranged from 25to $67 \mathrm{mg} / \mathrm{kg}$, being 38 an $51 \mathrm{mg} / \mathrm{kg}$ on average in sediments from the northern and southern lagoon, respectively. Concentrations of Sn ranged from 6 to $16 \mathrm{mg} / \mathrm{kg}$ in sediments from the southern lagoon and from 7 to $9 \mathrm{mg} / \mathrm{kg}$ in sediments from the northern lagoon, equal to 11 and $8 \mathrm{mg} / \mathrm{kg}$ on average, respectively. Concentrations of Ni ranged from 14 to $29 \mathrm{mg} / \mathrm{kg}$ (from 15 to $27 \mathrm{mg} / \mathrm{kg}$ in sediments from the northern lagoon), equal to 19 and 
$20 \mathrm{mg} / \mathrm{kg}$ in sediments from the southern and northern lagoon, respectively. Concentrations of $\mathrm{Pb}$ were found to range from 49 to $122 \mathrm{mg} / \mathrm{kg}$ in sediments from the southern lagoon and from 39 to $79 \mathrm{mg} / \mathrm{kg}$ in those from the northern lagoon, equal to 86 and $66 \mathrm{mg} / \mathrm{kg}$ on average, respectively. In turn, concentrations of $\mathrm{V}$ ranged from 8 to $21 \mathrm{mg} / \mathrm{kg}$ in sedimnts from the southern lagoon and from 9 to $25 \mathrm{mg} / \mathrm{kg}$ in those from the northern lagoon, equal to 11 and $15 \mathrm{mg} / \mathrm{kg}$ on average, respectively.

The mean concentrations of elements recorded in the sediments from the lagoons' floors were subsequently compared with admissible concentrations, as defined in the Regulation of the Ministry of Environment, $9^{\text {th }}$ September, 2002, on the standards of soil quality (Journal of Laws No. 165, item 1359). Table 4 shows results of these comparisons.
Mean concentrations of $\mathrm{As}, \mathrm{Co}, \mathrm{Mo}$ and $\mathrm{Ni}$ recorded for sediments from both lagoons fall within the limits of those mentioned above in the Regulation of the Ministry of Environment as admissible for soils in areas protected under the Water Law and Environmental Law and relevant regulations (Group A). The same is the case of $\mathrm{Cr}$ and $\mathrm{Hg}$ concentrations in sediments from the northern lagoon. In turn, mean concentrations of these elements in sediments from the southern lagoon exceed values admissible for soils in areas of the Group A, falling within the limits of values admissible for soils in areas of the Group B in theRegulation mentioned above (agricultural areas, forests and urban areas). In addition, mean concentrations of $\mathrm{Pb}$ (equal 86 and $66 \mathrm{mg} / \mathrm{kg}$ for sediments from the southern and northern lagoon, respectively) match values admissible for soils in areas of the Group B.

Table 4

A comparison of average metal content in the samples collected from northern and southern lagoons with the limit values set out in the legislation

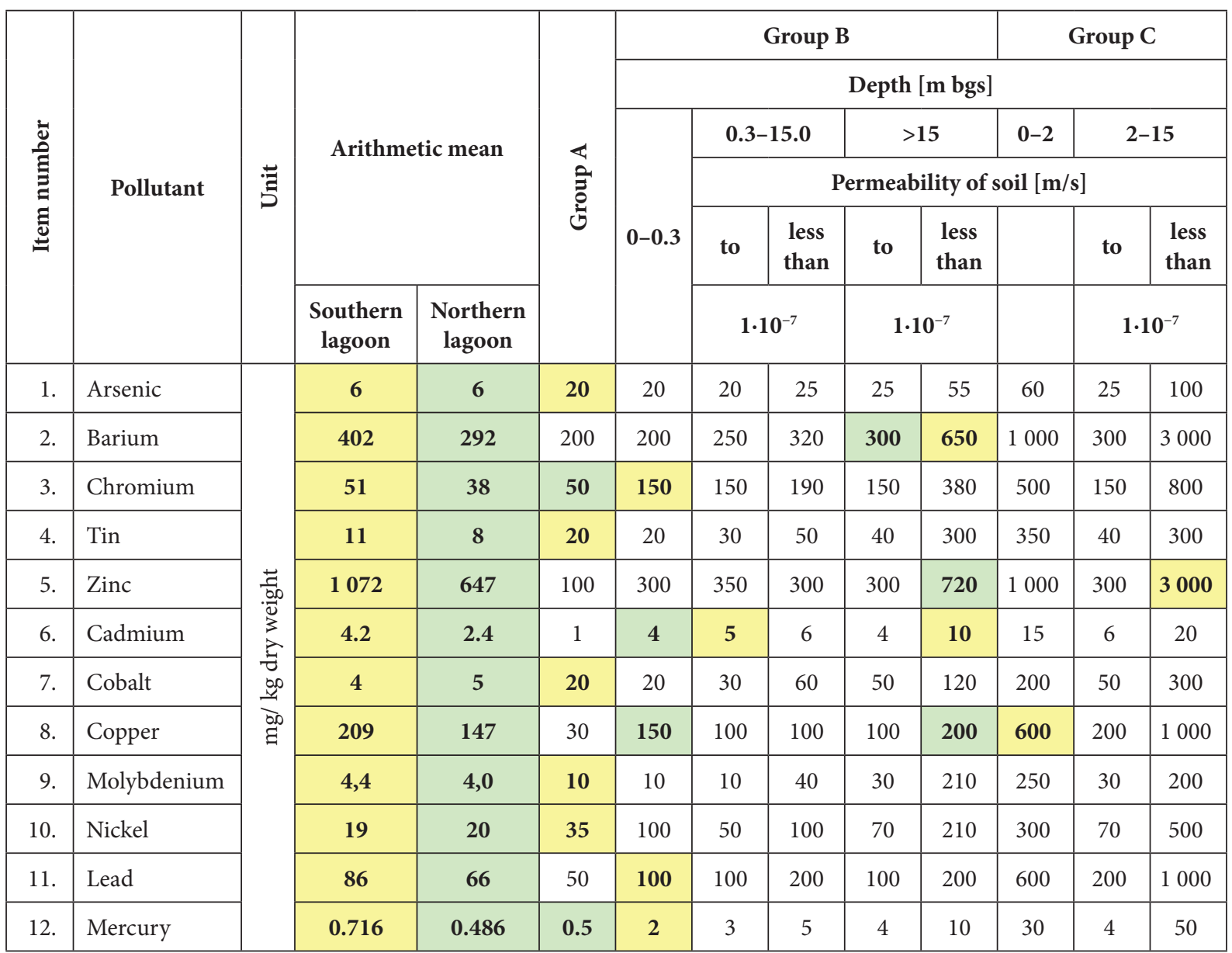


In the case of the remaining pollutants $(\mathrm{Ba}, \mathrm{Zn}$, $\mathrm{Cd}$ and $\mathrm{Cu}$ ), the situation appears more complex. Comparison of mean concentration values of $\mathrm{Cd}$ with the admissible levels showed that the value obtained for sediments from the northern lagoon $(2.4 \mathrm{mg} / \mathrm{kg})$ is lower than admissible for that pollutant in soils in areas of the Group B. In turn, mean concentration of that pollutant in sediments from the southern lagoon $(4.2 \mathrm{mg} / \mathrm{kg})$ is lower than admissible for soils in areas of the Group C (industrial areas, mining operations, communication traffic areas) as defined in the Regulation. At the same time, this value matches requirements set for soils in areas of the Group B in depth intervals of $0.3-15.0 \mathrm{~m}$ below the ground surface (bgs) and over $15 \mathrm{~m}$, when soil permeability is below $10^{-7} \mathrm{~m} / \mathrm{s}$. It should be noted, that the admissible concentrations are exceeded in the remaining cases (depth intervals $0.0-0.3 \mathrm{~m}$ and over $15 \mathrm{~m}$ bgs when soil permeability is up to $1 \cdot 10^{-7} \mathrm{~m} / \mathrm{s}$ ).

Mean content of $\mathrm{Cu}$ in sediments from the southern lagoon $(209 \mathrm{mg} / \mathrm{kg})$ is lower than admissible for soils in areas of the Group C, in depth intervals $0-2 \mathrm{~m}$ and $2-15 \mathrm{~m}$ (when soil permeability is less than $1 \cdot 10^{-7} \mathrm{~m} / \mathrm{s}$ ), and exceeds admissible limits as defined by the Regulation for the remaining cases. In turn, the average concentration of $\mathrm{Cu}$ in sediments from the northern lagoon $(147 \mathrm{mg} / \mathrm{kg})$ was lower than those admissible for Group $\mathrm{C}$ as well as the depth interval 0.0-0.3 $\mathrm{m}$ in soils of Group B.

Mean concentrations of $\mathrm{Ba}$ in sediments from the southern lagoon $(402 \mathrm{mg} / \mathrm{kg})$ falls within the interval of various limits established for soils in the areas of Group C. The recorded value is higher than admissible for the depth interval 2-15 $\mathrm{m}$ bgs with soil permeability up to $1 \cdot 10^{-7} \mathrm{~m} / \mathrm{s}$, not exceeding the remaining limits. In turn, the mean concentration of that pollutant in sediments from the northern lagoon $(292 \mathrm{mg} / \mathrm{kg})$ is lower than those for soils of Group C as well as those for Group B in the interval $0.3-15.0$ (under conditions of soil permeability below $1 \cdot 10^{-7} \mathrm{~m} / \mathrm{s}$ ) and at depths $>15 \mathrm{~m}$ bgs (under various conditions of soil permeability).

Mean concentrations of $\mathrm{Zn}$ in samples from both lagoons fall within the interval of various limits established for soils of areas of Group C. However, it should be noted that concentrations recorded in most samples of sediments from the northern lagoon are up to two times higher than the limit for the Group C levels in the case of the depth interval 2-15 $\mathrm{m}$ bgs and under soil permeability up to $1 \cdot 10^{-7} \mathrm{~m} / \mathrm{s}$. Concentrations in most samples from the southern lagoon, on the other hand,exceed two lower limits for soils of areas of Group C except for the limit for the depth interval $2-15 \mathrm{~m}$ bgs and soil permeability below $1 \cdot 10^{-7} \mathrm{~m} / \mathrm{s}$.

\section{CONCLUSIONS}

Sediments sampled from the floor of the facultative lagoons originated as a result of human activity and are connected with several decades of treatment of industrial and domestic wastewater. The analyses of the authors show that the lagoon bottom sediments consist of over $90 \%$ of mineral fraction, mainly kaolinite, calcite and quartz. The high share (over $30 \%$ ) of kaolinite is the direct result of the operations of the paper mill, as kaolinite was used for paper mass infill, to ensure gloss on some grades of paper. Zn oxide, in turn, was used to make the (cellulose) coating of paper whiter, brighter and more stable. The presence of neomorphic smithsonite (although in trace amounts) along with zinc occurring in higher concentration than the remaining pollutants further confirm the anthropogenic origin of the pollution. Zinc oxide is widely used in the cellulose and paper-making industry due to its whitening, matting and coating properties.

The work of this study has demonstarted that the southern lagoon was exposed to much stronger anthropopression. This is well proven by markedly higher concentrations of individual pollutants in samples from that lagoon than in those recorded in sediments from the northern lagoon. This regularity may be explained by the fact that industrial wastewater was first discharged to that part of the original facultative lagoon.

Comparisons of the recorded mean concentrations with admissible values, as defined in the Regulation of the Ministry of Environment, $9^{\text {th }}$ September, 2002, on the standards of soil quality (Journal of Laws No. 165, item 1359) showed that those of As, Sn, Co, Mo and Ni fall within the limits admissible for soils in areas of the Group A (areas under protection). In turn, mean concentrations of $\mathrm{Pb}$ and also $\mathrm{Hg}$ and $\mathrm{Cr}$ (in sediments 
from the northern lagoon) meet the standards defined for soils in areas of the Group B (agricultural lands, forests, urban areas). Mean concentrations of $\mathrm{Cu}$ and $\mathrm{Ba}$ in the southern lagoon as well as of $\mathrm{Zn}$ in both lagoons fall within the interval of various limits established for soils in areas of Group $\mathrm{C}$ (industrial areas), while mean concentrations of $\mathrm{Cu}$ and $\mathrm{Ba}$ in the northern lagoon and of $\mathrm{Cd}$ in both lagoons do not exceed any of them.

These data demonstrate that anthropogenic sediments removed from the facultative lagoons of the former industrial and domestic wastewater treatment plant at Konstancin-Jeziorna, near Warsaw, generally match current environmental standards, making it possible to use them in in the process of land reclamation and similar purposes.

The authors would like to thank prof. dr hab. Bogusław Wiłkomirski and dr Rimante Zinkute for their comments that greatly improved the manuscript.

\section{REFERENCES}

Bień J.B. \& Wystalska K., 2011. Osady ściekowe: teoria i praktyka. Wydawnictwa Politechniki Częstochowskiej, Częstochowa.

Bojakowska I., Dobek P. \& Wołkowicz S., 2012. Oddziaływanie na środowisko gruntowe stawów biologicznego oczyszczania ścieków. Górnictwo i Geologia, 7, 2, 59-69.

Dąbrowski J., 2011. Republishing the works of Włodzimierz Budka, a Polish paper historian. Paper History. Journal of International Association of Paper Historians, 15, 1, 16-28.

Drągowski A., 2010. Charakterystyka i klasyfikacja gruntów antropogenicznych. Przeglad Geologiczny, 58, 9/2, 868-872.

Gadomska D., Historia papierni w Jeziornie. Wirtualne Muzeum Konstancina, [on-line:] http://www.muzeumkonstancina.pl/47_fabryka_papieru_w_jeziornie [access: November 2014].

Rozporządzenie Ministra Środowiska z dnia 9 września 2002 r. w sprawie standardów jakości gleby oraz standardów jakości ziemi. Dz. U. nr 165, poz. 1359 [Journal of Law No. 165, item 1359].

Rozporządzenie Ministra Środowiska $z$ dnia 27 września 2001 r.w sprawie katalogu odpadów. Dz. U. nr 112, poz. 1206 [Journal of Law No. 112, item 1206] annulled and replaced by Rozporzadzenie Ministra Środowiska $z$ dnia 9 grudnia 2014 r. w sprawie katalogu odpadów. Dz. U. 2014, poz. 1923 [Journal of Laws of 2014, item 1923]. 